\title{
Postnatal Odor Exposure Increases the Strength of Interglomerular Lateral Inhibition onto Olfactory Bulb Tufted Cells
}

\author{
Matthew Geramita and Nathan N. Urban \\ Center for Neuroscience, and Center for the Neural Basis of Cognition, University of Pittsburgh, Pittsburgh, Pennsylvania 15213
}

\begin{abstract}
Lateral inhibition between pairs of olfactory bulb (OB) mitral cells (MCs) and tufted cells (TCs) is linked to a variety of computations including gain control, decorrelation, and gamma-frequency synchronization. Differential effects of lateral inhibition onto MCs and TCs via distinct lateral inhibitory circuits are one of several recently described circuit-level differences between MCs and TCs that allow each to encode separate olfactory features in parallel. Here, using acute $\mathrm{OB}$ slices from mice, we tested whether lateral inhibition is affected by prior odor exposure and if these effects differ between MCs and TCs. We found that early postnatal odor exposure to the M72 glomerulus ligand acetophenone increased the strength of interglomerular lateral inhibition onto TCs, but not MCs, when the M72 glomerulus was stimulated. These increases were specific to exposure to M72 ligands because exposure to hexanal did not increase the strength of M72-mediated lateral inhibition. Therefore, early life experiences may be an important factor shaping TC odor responses.
\end{abstract}

Key words: electrophysiology; lateral inhibition; olfaction; olfactory bulb; plasticity

\section{Significance Statement}

Responses of olfactory (OB) bulb mitral cells (MCs) and tufted cells (TCs) are known to depend on prior odor exposure, yet the specific circuit mechanisms underlying these experience-dependent changes are unknown. Here, we show that odor exposure alters one particular circuit element, interglomerular lateral inhibition, which is known to be critical for a variety of OB computations. Early postnatal odor exposure to acetophenone, a ligand of M72 olfactory sensory neurons, increases the strength of M72-mediated lateral inhibition onto TCs, but not MCs, that project to nearby glomeruli. These findings add to a growing list of differences between MCs and TCs suggesting that that these two cell types play distinct roles in odor coding.

\section{Introduction}

Determining how experience shapes sensory responses is vital for understanding how sensory information is processed in brain circuits. In the olfactory bulb $(\mathrm{OB})$, multiple studies have shown that responses of the two types of projection neurons, mitral cells (MCs) and tufted cells (TCs), depend on prior odor exposure (Buonviso and Chaput, 2000; Wilson, 2000; Fletcher and Wilson, 2003; Wilson and Linster, 2008; Kato et al., 2012), yet the specific circuit mechanisms behind these changes remain unknown.

Received June 22, 2016; revised Sept. 29, 2016; accepted Sept. 30, 2016.

Author contributions: M.G. and N.N.U. designed research;M.G. performed research;M.G. analyzed data;M.G. and N.N.U. wrote the paper

This work was supported by the National Institute of Deafness and Other Communication Disorders-National Institutes of Health (Grant R01-DC011184 to N.N.U.). We thank Shawn Burton, Claire Cheetham, and members of the Urban laboratory for helpful comments and discussion and Greg LaRocca for excellent technical assistance.

The authors declare no competing financial interests.

Correspondence should be addressed to Nathan N. Urban, Department of Neurobiology, University of Pittsburgh, E1440 BSTWR, 200 Lothrop Street, Pittsburgh, PA 15213. E-mail: nurban@pitt.edu.

DOI:10.1523/JNEUROSCI.1991-16.2016

Copyright $\odot 2016$ the authors $\quad 0270-6474 / 16 / 3612321-07 \$ 15.00 / 0$
Moreover, in contrast to the hippocampus and neocortex, few in vitro studies have been able to induce changes such as long-term potentiation (Gao and Strowbridge, 2009; Nissant et al., 2009) in the OB. Here, we demonstrate that odor exposure alters one critical circuit element, interglomerular lateral inhibition, and does so specifically for one class of $\mathrm{OB}$ output neurons: TCs.

MCs and TCs receive excitation from a single glomerulus, but inhibition from many, a process known broadly as lateral inhibition. Lateral inhibition is modulated by a variety of inhibitory interneuron subtypes that include superficial short axon cells (Liu et al., 2013; Whitesell et al., 2013; Banerjee et al., 2015), external plexiform layer interneurons (EPL-INs) (Kato et al., 2013; Miyamichi et al., 2013), and granule cells (GCs) (Arevian et al., 2008; Fukunaga et al., 2014; Gschwend et al., 2015). These circuits influence MC/TC activity in a variety of ways that include controlling gain (Banerjee et al., 2015), decorrelating odor representations (Arevian et al., 2008; Giridhar et al., 2011; Gschwend et al., 2015), modulating spike timing (Fukunaga et al., 2014), and synchronizing gamma-frequency oscillations (Lagier et al., 2004; Galán et al., 2006; Lagier et al., 2007; Fukunaga et al., 2014). The 
effects of sensory experience have been studied most extensively in GCs because previous work has shown that prior odor exposure influences GC survival (Lemasson et al., 2005; Saghatelyan et al., 2005; Alonso et al., 2006), morphology (Saghatelyan et al., 2005; Yoshihara et al., 2012), and in vivo odor responses (Kato et al., 2012). Whether experience-dependent changes in interneurons leads to changes in interglomerular lateral inhibition onto MCs and TCs is unknown.

Although MCs and TCs have distinct morphologies (Mori et al., 1983; Orona et al., 1984; Burton and Urban, 2014) and send axons to largely nonoverlapping cortical areas (Haberly and Price, 1977; Igarashi et al., 2012), only recently have their functional differences been described and their distinct roles in odor coding hypothesized. For instance, MC and TC odor responses differ in the timing of activation (Fukunaga et al., 2012; Igarashi et al., 2012), concentration dependence (Nagayama et al., 2004; Fukunaga et al., 2012; Igarashi et al., 2012), influence of neuromodulators (Kapoor et al., 2016), cortical feedback (Otazu et al., 2015), and lateral inhibition (Nagayama et al., 2004). Despite this recent push to consider MCs and TCs as functionally distinct neuron types, little is known about whether sensory experience affects MCs and TCs differentially. However, lateral inhibition affects spiking in MCs and TCs differently in part due to differences in connectivity to superficial GCs (sGCs) and deep GCs (dGCs), respectively, two subclasses of granule cells (Geramita et al., 2016). In addition, early olfactory experience increases the survival of GCs born in the early postnatal period (P3-P14), the majority of which are sGCs, but has no effect on the survival of GCs born later (P14-P60), the majority of which are dGCs (Lemasson et al., 2005). Therefore, early postnatal odor exposure may more strongly affect lateral inhibition onto TCs than onto MCs.

Here, we show, in M72-ChR2-YFP mice (Smear et al., 2013), that postnatal exposure to acetophenone (Ace), a ligand of the M72 glomerulus, increases the strength of M72-mediated lateral inhibitory currents onto TCs, but not MCs. In addition, we show that this increase in lateral inhibition onto TCs is specific to exposure to M72 ligands.

\section{Materials and Methods}

Odor exposure. As described previously (Kerr and Belluscio, 2006), beginning at $\mathrm{P} 0$ and ending at P20, litters of M72-ChR2-YFP mice (Smear et al., 2013) including pups of both sexes were exposed to one of three odor stimuli through daily application to the nipples of the dam: (1) $50 \mu \mathrm{l}$ of mineral oil (MO), (2) $50 \mu \mathrm{l}$ of a 1:100 (v/v) dilution of the M72 ligand Ace in MO, or (3) $50 \mu \mathrm{l}$ of a 1:100 (v/v) dilution of the non-M72 ligand hexanal (Hex) in MO.

Slice preparation. P17-P20 M72-ChR2-YFP mice of both sexes were anesthetized with isoflurane and decapitated. Brains were dissected into ice-cold oxygenated solution containing the following (in $\mathrm{mm}$ ): 125 $\mathrm{NaCl}, 25$ glucose, $2.5 \mathrm{KCl}, 25 \mathrm{NaHCO}_{3}, 1.25 \mathrm{NaH}_{2} \mathrm{PO}_{4}, 7 \mathrm{MgCl}_{2}$, and 0.5 $\mathrm{CaCl}_{2}$. Sagittal slices $(280 \mu \mathrm{m}$ thick) of the main olfactory bulb were prepared using a vibratome (VT1200S; Leica) and recovered for 15-30 min in $37^{\circ} \mathrm{C}$ oxygenated Ringer's solution that was identical to the dissection solution except for lower $\mathrm{Mg}^{2+}$ concentrations $(1 \mathrm{~mm} \mathrm{MgCl}$ ) and higher $\mathrm{Ca}^{2+}$ concentrations $\left(2 \mathrm{mM} \mathrm{CaCl}_{2}\right.$ ). Before recording, slices were stored in room temperature oxygenated Ringer's solution until recording.

Cell classification. TCs were identified as those cells residing completely in the superficial half of the EPL with large somas ( $>10 \mu \mathrm{m}$ in diameter). All TCs had at least one lateral dendrite and did not display the rhythmic bursting characteristic of external TCs (Hayar et al., 2004; Antal et al., 2006; Liu and Shipley, 2008). MCs were identified as large cells located in the MC layer (MCL). Those cells with somata that only partially reside in the MCL ("displaced MCs," Mori et al., 1983; or “internal TCs," Igarashi et al., 2012) were excluded from analysis due to the possibility of misidentification as MCs or TCs.

Electrophysiology. M/TCs were visualized using infrared differential interference contrast video microscopy. Throughout the recording process, slices were continuously superfused with $37^{\circ} \mathrm{C}$ oxygenated Ringer's solution that contained $0.2 \mathrm{mM} \mathrm{Mg}^{2+}$ to enhance NMDAR activation and granule-cell-mediated inhibition (Arevian et al., 2008; Abraham et al., 2010; Dietz et al., 2011). Voltage-clamp recordings were made using electrodes filled with the following (in $\mathrm{mm}$ ): 140 Cs-gluconate, 10 HEPES, $2 \mathrm{KCl}, 10$ sodium phosphocreatine, $3 \mathrm{Mg}$-ATP, $0.3 \mathrm{Na}_{3} \mathrm{GTP}$, and 0.25 Alexa Fluor 594 (Life Technologies) plus $0.2 \%$ Neurobiotin (Vector Labs). All data were low-pass filtered at $4 \mathrm{kHz}$ and digitized at $10 \mathrm{kHz}$ using a MultiClamp 700A amplifier (Molecular Devices) and an ITC-18 acquisition board (Instrutech) controlled by custom software written in Igor Pro (WaveMetrics). M72 photostimulation was provided by a 250 $\mu \mathrm{m}$ multimode optical fiber (Thorlabs) coupled to a high-intensity lightemitting diode (M470F1; Thorlabs) and driver (DC2100; Thorlabs) controlled by transistor-transistor logic pulses.

Data analysis. Inhibitory currents were measured in seven trials at a holding potential of $+10 \mathrm{mV}$ using a single $10 \mathrm{~ms}$ light pulse. Spontaneous IPSCs (sIPSCs) in M/TCs were measured in four $30 \mathrm{~s}$ trials. Analysis of M72-mediated inhibitory currents was performed using custom Matlab (The MathWorks) analysis software. The presence or absence of IPSCs was calculated by taking the average trace of seven trials and finding the mean and SD of the trace during the second before photostimulation. Then, the baseline current (mean of the second before photostimulation) was subtracted from each trace. Lateral inhibitory currents were present if positive deflections of the current trace exceeded $3^{*} \mathrm{SD}$ for longer than $10 \mathrm{~ms}$ in the $500 \mathrm{~ms}$ time window after M72 photostimulation. Lateral inhibitory currents were subsequently split into early $(0-250 \mathrm{~ms})$ and late $(250-1500 \mathrm{~ms})$ phases and the peak current amplitude and charge transfer were calculated in each. Charge transfer was calculated as the integral of the current trace in either the early phase or late phase after photostimulation. sIPSCs were detected using a standard template-matching function from Axograph (Clements and Bekkers, 1997) that included a 21-ms-long double-exponential template with a $5 \mathrm{~ms}$ baseline, $2 \mathrm{~ms}$ rise time, and $10 \mathrm{~ms}$ decay constant. All events were detected with a threshold amplitude of $2^{\star} \mathrm{SD}$ of the baseline noise. Spurious event detections with rise times $>5 \mathrm{~ms}$ and decay constants $>100 \mathrm{~ms}$ or $<2 \mathrm{~ms}$ were excluded from analysis.

\section{Results}

Analyzing experience-dependent changes in brain circuitry is facilitated by approaches that allow experience-activated regions or cells to be identified specifically across animals (Barth, 2007; Espinosa and Stryker, 2012). Here, we combined the use of a stimulus (Ace) that activates a known receptor (M72) in animals in which this receptor is labeled (M72-ChR2-YFP) to achieve selective activation of a single glomerulus across animals (Smear et al., 2013). This approach allowed us to measure the strength of M72mediated lateral inhibition in M/TCs in acute OB slices. Beginning at P0, M72-ChR2-YFP litters were split into three groups and exposed to one of three odor stimuli (see Material and Methods): (1) MO; (2) Ace, an odor that activates the M72 glomerulus (Feinstein et al., 2004; Zhang et al., 2012); or Hex, an odor that does not activate the M72 glomerulus (Smear et al., 2013) but does activate many olfactory receptor neurons targeting the dorsal surface of the OB.

Between P17 and P20, we cut OB slices from M72-ChR2-YFP mice and optogenetically activated the M72 glomerulus (10 ms light pulse) while recording inhibitory currents in MCs and TCs that innervate nearby glomeruli (Fig. $1 a, c$ ). M72 photostimulation evoked reliable and long-lasting inhibitory currents onto MCs and TCs (Fig. 1d). We quantified the strength of lateral inhibition by measuring light-evoked inhibitory currents in MCs and TCs at early $(<250 \mathrm{~ms})$ and late $(>250 \mathrm{~ms})$ times after stim- 


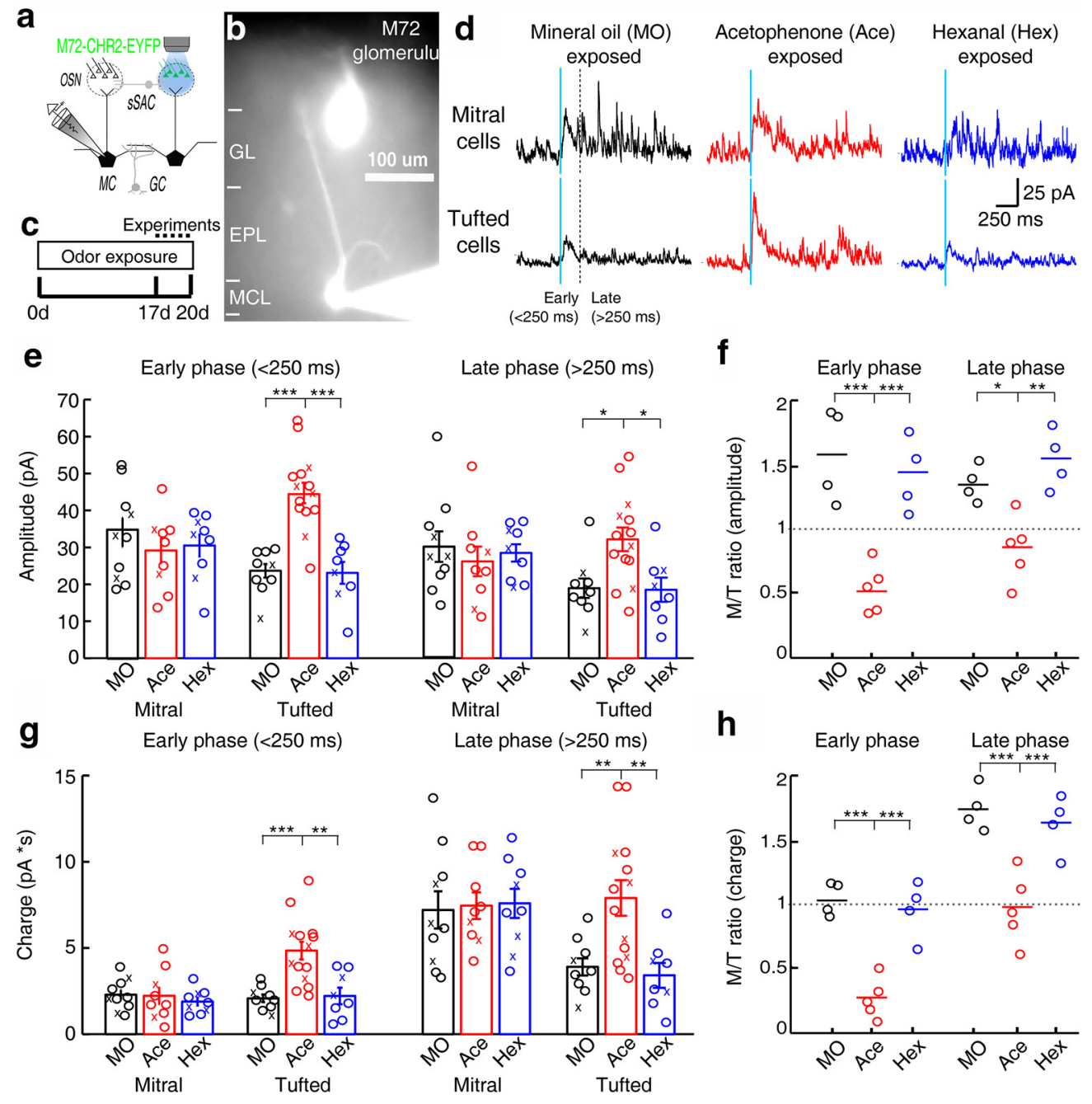

Figure 1. Postnatal exposure to the M72 ligand Ace increases the strength of M72-mediated lateral inhibition onto TCs, but not MCs. $\boldsymbol{a}, \boldsymbol{b}$, Schematic and example of recording from a MC that projects to a glomerulus near the M72 glomerulus in M72-ChR2-YFP mice. GL, Glomerular layer. Photostimulation of the M72 glomerulus (10 ms light pulse) evokes inhibitory currents. c, Litters were exposed to M0, Ace, or Hex beginning at P0 by daily application of the odor to the nipples of the dam. Experiments measuring M72-mediated lateral inhibition are performed between P17 and P20. d, Examples of M72-mediated lateral inhibition onto MCs (top) or TCs (bottom) from M0-exposed mice (left; black), Ace-exposed mice (middle; red), or Hex-exposed mice (right; blue). Inhibitory responses were grouped into early phase $(<250 \mathrm{~ms})$ and late phase $(>250 \mathrm{~ms})$ responses. $\boldsymbol{e}-\boldsymbol{h}$, Both the peak amplitude $(\boldsymbol{e})$ and charge transferred $(\boldsymbol{g})$ of early and late phases of inhibition are increased in TCs, but not MCs, from Ace-exposed animals ("x" indicates cells lacking an apical dendrite). The MC/TC ratio of the peak amplitude $(\boldsymbol{f})$ or charge transferred ( $\boldsymbol{h})$ between cells recorded sequentially in the same slice was significantly reduced in Ace-exposed animals. Data were taken from 24MCs (M0: 10 cells, 8 animals, 2 litters; Ace: 9 cells, 9 animals, 3 litters; Hex: 9 cells, 8 animals, 2 litters) and 30 TCs (M0: 9 cells, 8 animals, 2 litters; Ace: 14 cells, 10 animals, 3 litters; Hex: 8 cells, 5 animals, 2 litters). ${ }^{*} p<0.05,{ }^{* *} p<0.01,{ }^{* * *} p<0.001$. Data are presented as mean \pm SEM.

ulus onset. MCs from MO-exposed animals received stronger lateral inhibitory currents than TCs from MO-exposed animals (Fig. $1 e-h)$. The peak amplitude (MC: $34.9 \pm 11.9$ pA; TC: $24.2 \pm$ $6.0 \mathrm{pA} ; p=0.026$, unpaired $t$ test), but not the charge transferred (MC: $2.45 \pm 0.92 \mathrm{pA}^{*}$; TC: $2.32 \pm 0.69 \mathrm{pA}^{\star} \mathrm{s} ; p=0.72$, unpaired $t$ test), of early phase inhibition was significantly larger in MCs than in TCs from MO-exposed animals. In addition, both the peak amplitude (MC: $30.9 \pm 13.1$; TC: $19.4 \pm 7.98$; $p=0.036$, unpaired $t$ test) and charge transferred (MC: $7.30 \pm 3.39 \mathrm{pA}^{\star} \mathrm{s}$; TC: $4.16 \pm 1.54 \mathrm{pA}^{\star} s ; p=0.021$, unpaired $t$ test) of late phase inhibition was significantly larger in MCs than in TCs from MOexposed animals. Together, these data and our previous work (Geramita et al., 2016) demonstrate that M72-mediated lateral inhibition is stronger onto MCs than onto TCs.

In Ace-exposed, but not Hex-exposed, animals, the strength of M72-mediated lateral inhibition onto TCs, but not MCs, was increased. In TCs from Ace-exposed animals, the amplitude (early phase: MO, $24.19 \pm 6.0 \mathrm{pA}$; Ace, $45.59 \pm 10.64 \mathrm{pA}$, Hex,
$24.08 \pm 8.03 \mathrm{pA}, p=1.5 \mathrm{e}-6$; late phase: $\mathrm{MO}, 19.44 \pm 7.98 \mathrm{pA}$, Ace, $32.16 \pm 12.0 \mathrm{pA}, \mathrm{Hex}, 19.94 \pm 9.69 \mathrm{pA}, p=9.5 \mathrm{e}-3$; one-way, ANOVA; Fig. 1e) and charge transferred (early phase: MO, $2.32 \pm 0.69 \mathrm{pA}^{\star} \mathrm{s}$, Ace, $4.90 \pm 1.92 \mathrm{pA}^{\star} \mathrm{s}, \mathrm{Hex}, 2.53 \pm 1.28 \mathrm{pA}^{\star} \mathrm{s}$, $p=4.0 \mathrm{e}-4$; late phase: $\mathrm{MO}, 4.16 \pm 1.54 \mathrm{pA}^{\star} \mathrm{s}$, Ace, $8.01 \pm 3.73$ $\mathrm{pA}^{\star} \mathrm{s}, \mathrm{Hex}, 3.74 \pm 1.92 \mathrm{pA}^{\star} \mathrm{s}, p=0.0019$; one-way ANOVA; Fig. $1 \mathrm{~g}$ ) of the early and late phases of inhibition were significantly larger compared with currents from TCs in MO-exposed or Hexexposed animals. In contrast, neither the amplitude (early phase: MO, $34.96 \pm 11.97$ pA, Ace, $29.61 \pm 9.97$ pA, Hex, $31.20 \pm 9.29$ pA, $p=0.53$; late phase: MO, $30.95 \pm 13.06$ pA, Ace, $26.45 \pm$ $12.23 \mathrm{pA}, \mathrm{Hex}, 19.94 \pm 9.69 \mathrm{pA}, p=0.68$ one-way ANOVA) nor charge transferred (early phase: $\mathrm{MO}, 2.45 \pm 0.92 \mathrm{pA}^{\star} \mathrm{s}$, Ace, $2.43 \pm 1.44 \mathrm{pA}^{\star} \mathrm{s}$, Hex, $2.18 \pm 0.72 \mathrm{pA}^{\star} \mathrm{s}, p=0.83$; late phase: $\mathrm{MO}, 7.30 \pm 3.39 \mathrm{pA}^{\star} \mathrm{s}$, Ace, $7.57 \pm 2.30 \mathrm{pA}^{\star} \mathrm{s}$, Hex, $7.64 \pm 2.54$ $\mathrm{pA}^{\star} \mathrm{s}, p=0.96$ one-way ANOVA) of the early or late phases of inhibition onto MCs changed after exposure to Ace. Therefore, 
postnatal exposure to a ligand that activates the M72 glomerulus specifically increased the strength of M72-mediated lateral inhibition onto TCs, but not MCs.

We next explored other factors that may influence the strength of lateral inhibition. To control for slice-to-slice variability in the strength of lateral inhibition, we examined the ratio of MC/TC inhibition in pairs of cells recorded sequentially in the same slice. This ratio was significantly reduced in Ace-exposed animals (Fig. 1f; amplitude: early phase: MO, $1.60 \pm 0.36$, Ace, $0.50 \pm 0.20$, Hex, $1.42 \pm$ $0.27, p=3 \mathrm{e}-4$, late phase: MO, $1.38 \pm$ 0.18 , Ace, $0.86 \pm 0.27$, Hex, $1.53 \pm 0.24$, $p=0.003$; Fig. $1 h$; charge: early phase: MO, $1.05 \pm 0.14$, Ace, $0.25 \pm 0.17$, Hex, $0.97 \pm 0.24, p=1 \mathrm{e}-4$, late phase: MO, $1.75 \pm 0.19$, Ace, $0.98 \pm 0.31$, Hex, $1.64 \pm$ $0.21, p=0.001$; one-way ANOVA). There were no differences in the proportion of MCs (MO, 10/18, 56\%; Ace, 9/18, 50\%; Hex, 9/20, 45\%) and TCs (MO, 9/15, $60 \%$; Ace, 14/25, 56\%; Hex, 8/14, 57\%) that received lateral inhibition between the 3 odor-exposed groups. Moreover, the MCs (MO: $123 \pm 86 \mu \mathrm{m}$; Ace: $148 \pm 97$ $\mu \mathrm{m}$; Hex: $135 \pm 75 \mu \mathrm{m}, p=0.72$; oneway ANOVA) and TCs (MO: $84 \pm 62 \mu \mathrm{m}$; Ace: $73 \pm 56 \mu \mathrm{m}$; Hex: $77 \pm 46 \mu \mathrm{m}, p=$ 0.82 ; one-way ANOVA) recorded in the 3 groups were similar distances from the M72 glomerulus. In addition, the strength of lateral inhibition did not depend on whether the apical dendrite was intact, as described previously (Geramita et al., 2016). TCs without apical dendrites from Aceexposed mice showed similar increases in the amplitude and charge of lateral inhibition compared with TCs with apical dendrites from Ace-exposed mice (amplitude: early phase: with apical, $46.3 \pm 11.72 \mathrm{pA}$, without apical, $43.80 \pm 8.5 \mathrm{pA}, p=0.71$; late phase: with apical, $32.11 \pm 13.25 \mathrm{pA}$, without apical, $32.3 \pm 9.83$ $\mathrm{pA}, p=0.98$; charge: early phase: with apical, $5.02 \pm 2.21 \mathrm{pA}^{\star} \mathrm{s}$, without apical, $4.60 \pm 1.03 \mathrm{pA}^{\star} \mathrm{s}, p=0.73$; late phase: with apical, $8.27 \pm 4.14 \mathrm{pA}^{\star}$ s, without apical, $7.38 \pm 2.85 \mathrm{pA}^{\star} \mathrm{s}, p=0.70$, unpaired $t$ test). Therefore, either GCs or other EPL-INs are the most likely source of the experience-dependent increases in lateral inhibition described here.

In addition, we assessed whether the extent of the increase in M72-mediated lateral inhibition scaled with the total amount of M72 activation. To do this, we relied on the fact that the same odor is painted on the dam at the same concentration each day, so mice that were killed at $\mathrm{P} 20$ for recording received three more days of odor exposure than mice that were killed at P17. Therefore, if the strength of plasticity depends on the extent of M72 activation, then TCs from Ace-exposed mice killed at P20 should receive stronger M72-mediated lateral inhibition than TCs from Ace-exposed mice killed at P17. Indeed, we found that the amplitude of the early phase of M72-mediated lateral inhibition onto TCs from Ace-exposed animals was significantly correlated with the age of the animal when the recording was performed $(r=$ $0.64, p=0.014$; Fig. $2 a$ ). This correlation was not due to devel-
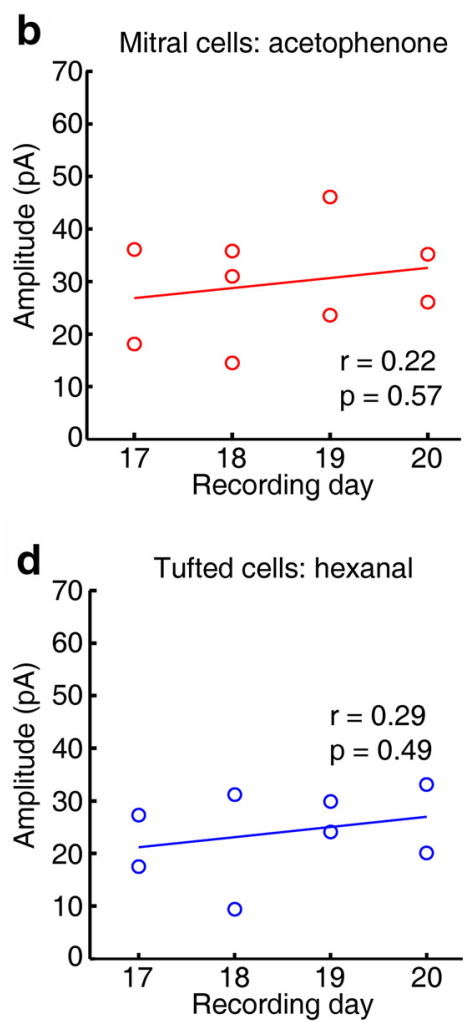

Figure 2. Extent of the increase in M72-mediated lateral inhibition onto TCs after Ace exposure scales with the total amount of 2 activation. $\boldsymbol{a}$, Amplitude of the early phase of M72-mediated lateral inhibition onto TCs from Ace-exposed animals is signif-

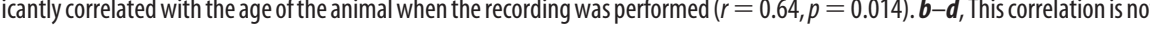
the strength of lateral inhibition onto TCs from M0-exposed $(\boldsymbol{c} ; r=0.17, p=0.66)$ or Hex-exposed $(\boldsymbol{d} ; r=0.29,0.49)$ animals Significance was assessed using Pearson's correlation.

opmental increases in the strength of lateral inhibition because there was no correlation between animal age and the strength of lateral inhibition onto MCs from Ace-exposed animals $(r=0.22$, $p=0.57$; Fig. $2 b$ ). In addition, we found no correlation between animal age and the strength of lateral inhibition onto TCs from MO-exposed ( $r=0.17, p=0.66$; Fig. $2 c)$ or Hex-exposed $(r=$ $0.29, p=0.49$; Fig. $2 d$ ) animals. Therefore, our newly described plasticity of M72-mediated lateral inhibition onto TCs depends on the amount of activation of the M72 glomerulus.

Finally, we tested an alternative mechanism that could lead to the increases in M72-mediated lateral inhibition described above. If the recorded MC/TC projected to a glomerulus that was activated by Ace and consequently experienced an experiencedependent increase in the total amount of recurrent inhibition that it receives, which occurs in vivo (Saghatelyan et al., 2005), then lateral inhibition originating from all other connected glomeruli, including the M72 glomerulus, would increase due to the reciprocal nature of the dendrodendritic synapse. To examine this possibility, we measured sIPSCs in MCs and TCs from the three odor-exposed groups (Fig. $3 a$ ) as a measure of the total amount of recurrent inhibition onto the cell. Neither sIPSC amplitude nor frequency differed in MCs (amplitude: $p=0.65$; frequency: $p=0.96$; one-way ANOVA) or TCs (amplitude: $p=$ 0.69 ; frequency: $p=0.95$; one-way ANOVA) (Fig. $3 b, c$ ) between the three odor-exposed groups. In addition, after grouping all 3 odor exposure conditions together by cell type, we found that both sIPSC amplitude ( $p=5.08 \mathrm{e}-5$, unpaired $t$ test $)$ and frequency ( $p=2.29 \mathrm{e}-7$, unpaired $t$ test $)$ were larger in MCs than in 
a
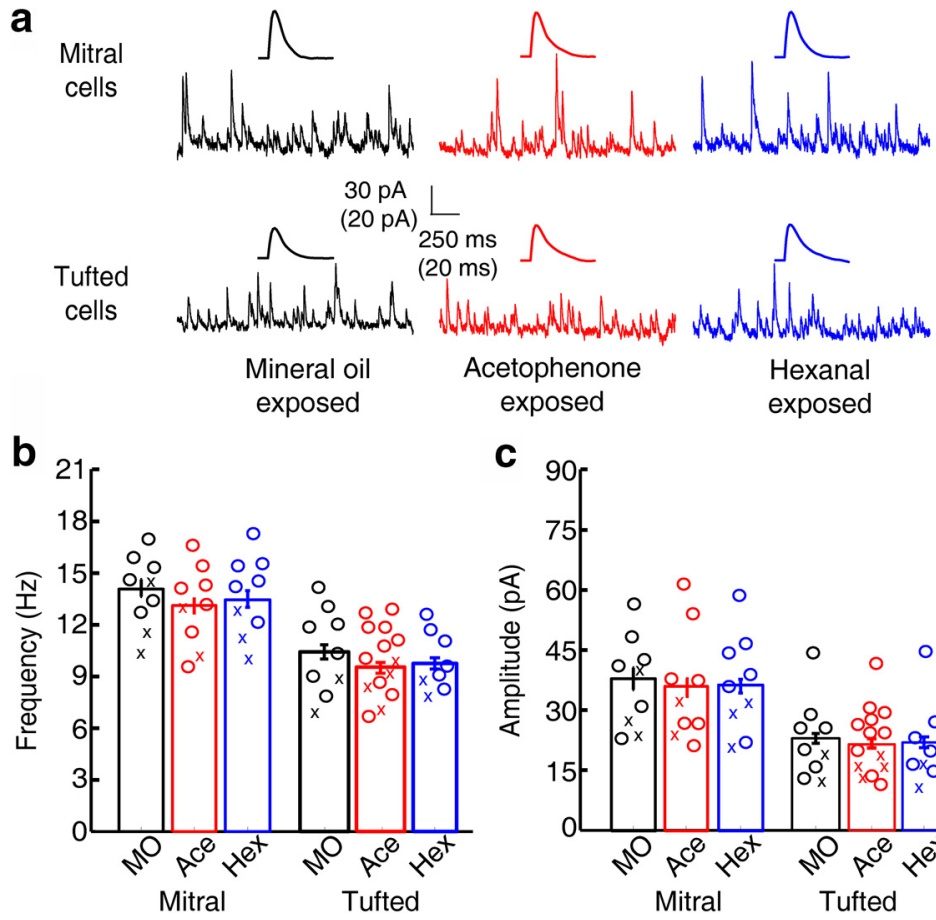

$250 \mathrm{~ms}$ $(20 \mathrm{~ms})$ H.

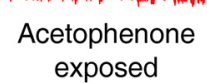

C

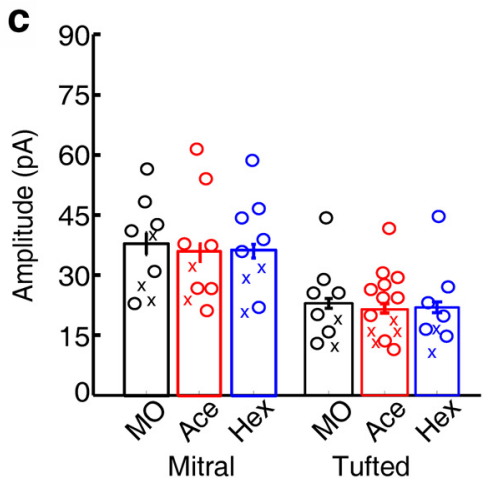

Figure 3. Postnatal odor exposure does not affect the frequency or amplitude of $\mathrm{SIPSC}$ in M/TCs innervating glomeruli near the M72 glomerulus. $\boldsymbol{a}$, Representative traces (2 s) of sIPSCs and the average sIPSC in MCs (top) and TCs (bottom) from M0-exposed (black), Ace-exposed (red), or Hex-exposed (blue) mice. Average sIPSCs are calculated from 14,848 events in M0-exposed MCs (9 cells, 8 animals, 2 litters); 13,793 events in Ace-exposed MCs ( 9 cells, 9 animals, 3 litters); 14,564 events in Hex-exposed (9 cells, 8 animals, 2 litters) MCs. Average sIPS(s are calculated from 11,392 events in M0-exposed TCs ( 9 cells, 8 animals, 2 litters); 16,458 events in Ace-exposed TCs (14 cells, 10 animals, 3 litters); 9646 events in Hex-exposed TCs (8 cells, 5 animals, 2 litters). b, c, sIPSC frequency $(\boldsymbol{b})$ and amplitude $(\boldsymbol{c})$ do not differ between MCs and TCs from M0-exposed, Ace-exposed, and Hex-exposed mice. " $x$ " indicates cells lacking an apical dendrite.

TCs. Therefore, increases in the strength of M72-mediated lateral inhibition are most likely due to specific experience-dependent changes in inhibitory circuitry caused by M72 activation.

\section{Discussion}

Our data provide the first evidence of experience-dependent changes in interglomerular lateral inhibition onto TCs. We show that postnatal exposure to the M72 ligand Ace increases the strength of M72-mediated lateral inhibition onto TCs, but not MCs. This differential influence of postnatal odor exposure in TCs is specific to Ace because TCs from mice exposed to Hex did not show increases in the strength of M72-mediated lateral inhibition. In addition, neither sIPSC frequency nor amplitude was altered by Ace or Hex exposure, indicating that increases in M72mediated lateral inhibition cannot be explained by increases in the total amount of inhibition onto the recorded M/TC.

Experience-dependent changes to the strength of interglomerular lateral inhibition onto TCs could have multiple physiological and/or computational roles. Increasing the strength of lateral inhibition originating from Ace-sensitive glomeruli may serve to silence weakly activated TCs and thus to increase the sparseness of and/or decorrelate odor representations encoded by TC populations. Similarly, prior odor experience in adulthood reduces the activity of many individual MCs to experienced odors so that MC representations of the experienced odor become sparser (Kato et al., 2012). In addition, increasing the strength of M72-mediated lateral inhibition may serve to shift spike timing, increase gamma synchrony, or improve decorrelation, all of which are mediated by GCs (Lagier et al., 2004; Galán et al., 2006; Lagier et al., 2007; Giridhar et al., 2011;
Fukunaga et al., 2014) and play important roles in olfactory-mediated behaviors (Lepousez and Lledo, 2013). Finally, limiting experience-dependent changes to TCs, but not MCs, may lead to other specific behavioral benefits. Prior work has shown that, due to differences in lateral inhibition, MCs and TCs are able to best discriminate between similar odors presented at high and low concentrations, respectively, and has suggested that MCs and TCs are responsible for separate concentration ranges (Geramita et al., 2016). Sparser TC odor representations due to experience-dependent increases in lateral inhibition may increase an animal's odor detection threshold while leaving $\mathrm{MC}$ representations unaffected. Ultimately, these differential effects of experience on TCs and MCs may allow the animal to better identify other odors present in a background of Ace. These potential benefits can be tested directly by determining whether Ace-exposed animals have lower detection thresholds for Ace or if they are better at identifying other odors in an Ace background.

Although a variety of specific changes to the $\mathrm{OB}$ circuit could explain the experience-dependent increases in TC lateral inhibition described here, prior work suggests that GCs are the most plausible source of these changes. Multiple aspects of GC physiology are known to be altered by olfactory experience: odor deprivation decreases the probability of GC survival, the complexity of GC dendritic arbors, and GC spine density (Saghatelyan et al., 2005), whereas postnatal odor exposure increases the probability of GC survival (Lemasson et al., 2005). Therefore, increases in either the number of GCs activated by M72 activation or the number of synapses formed by these GCs could explain the increases in M72mediated lateral inhibition. However, changes to other types of inhibitory interneurons are also possible. In particular, EPL-INs can mediate inhibition onto M/TCs (Kato et al., 2013; Miyamichi et al., 2013) and the strength of EPL-IN-mediated inhibition may be experience dependent. Glomerular layer circuits have also been shown to play a role in lateral inhibition (Liu et al., 2013; Whitesell et al., 2013; Banerjee et al., 2015), but these circuits are unlikely to play a role in the experience dependence of lateral inhibition reported here because the effects are not influenced by apical dendrite truncation. However, plasticity in glomerular circuits may alter the responsiveness of TCs other than the recorded cell, which may engage GCs that target the recorded TC and increase the amount of recorded lateral inhibition despite a truncated apical dendrite. Therefore, we cannot rule out the possibility that glomerular layer circuits contribute to the experience dependence of lateral inhibition described here. Finally, any mechanism that increases activity in M72-associated M/TCs could increase activity in interneurons and consequently lateral inhibition onto surrounding TCs. These include experiencedependent increases in the strength of olfactory receptor neuron input to M72-M/TCs, the intrinsic excitability of M72-M/TCs, or the number of M72-M/TCs. However, these mechanisms would be unlikely to affect MCs and TCs differentially. In addition, 
prior in vivo work showed that the vast majority of MCs show reductions in responsiveness after repeated odor exposure (Kato et al., 2012). However, this prior work exposed mice to odors in adulthood rather than during neonatal development. Given the fact that plasticity in many brain areas is enhanced during developmental critical periods (Erzurumlu and Gaspar, 2012; Espinosa and Stryker, 2012), experience-dependent increases in M72-M/TC activity during this neonatal period may occur. Therefore, determining the extent to which either excitatory synaptic input or intrinsic excitability increase in M72-M/TCs after Ace exposure is an important future direction. Although GCs remain the most plausible source of experience-dependent plasticity of lateral inhibition, we cannot rule out the possibility that other cell types may be the source of this effect.

Why is lateral inhibition onto TCs, but not MCs, influenced by postnatal odor exposure? This difference may reflect anatomical separation between sources of MC and TC lateral inhibition. The segregation of TC and sGC dendrites in the superficial EPL and MC and dGC dendrites in the deep EPL (Mori et al., 1983; Orona et al., 1983; Orona et al., 1984; Mori, 1987), as well as the distinct functional effects of lateral inhibition onto MCs and TCs (Geramita et al., 2016), suggest that TCs and MCs receive at least partially segregated inhibition from sGCs and dGCs, respectively. In addition, several lines of evidence suggest that sGCs are more strongly influenced by early odor exposure compared with dGCs. First, subsets of sGCs expressing the glycoprotein 5T4 are known to undergo experience-dependent changes in dendritic complexity (Yoshihara et al., 2012). Second, sGCs and dGCs are born at different times during the animal's life: sGCs are typically born during the first few weeks of life (Lemasson et al., 2005), whereas dGCs are born throughout life (Kelsch et al., 2007). Importantly, early odor exposure increases the probability of survival of GCs born in the early postnatal period (P3-P7) (mainly sGCs), but not GCs born later (mainly dGCs) (Lemasson et al., 2005). Therefore, differential effects of activity on sGCs and dGCs during the early postnatal period provide the most likely explanation of plasticity of lateral inhibition onto TCs, but not MCs.

\section{References}

Abraham NM, Egger V, Shimshek DR, Renden R, Fukunaga I, Sprengel R, Seeburg PH, Klugmann M, Margrie TW, Schaefer AT, Kuner T (2010) Synaptic inhibition in the olfactory bulb accelerates odor discrimination in mice. Neuron 65:399-411. CrossRef Medline

Alonso M, Viollet C, Gabellec MM, Meas-Yedid V, Olivo-Marin JC, Lledo PM (2006) Olfactory discrimination learning increases the survival of adult-born neurons in the olfactory bulb. J Neurosci 26:10508-10513. CrossRef Medline

Antal M, Eyre M, Finklea B, Nusser Z (2006) External tufted cells in the main olfactory bulb form two distinct subpopulations. Eur J Neurosci 24:1124-1136. CrossRef Medline

Arevian AC, Kapoor V, Urban NN (2008) Activity-dependent gating of lateral inhibition in the mouse olfactory bulb. Nat Neurosci 11:80-87. CrossRef Medline

Banerjee A, Marbach F, Anselmi F, Koh MS, Davis MB, Garcia da Silva P, Delevich K, Oyibo HK, Gupta P, Li B, Albeanu DF (2015) An Interglomerular circuit gates glomerular output and implements gain control in the mouse olfactory bulb. Neuron 87:193-207. CrossRef Medline

Barth AL (2007) Visualizing circuits and systems using transgenic reporters of neural activity. Curr Opin Neurobiol 17:567-571. CrossRef Medline

Buonviso N, Chaput M (2000) Olfactory experience decreases responsiveness of the olfactory bulb in the adult rat. Neuroscience 95:325-332. Medline

Burton SD, Urban NN (2014) Greater excitability and firing irregularity of tufted cells underlies distinct afferent-evoked activity of olfactory bulb mitral and tufted cells. J Physiol 592:2097-2118. CrossRef Medline
Clements JD, Bekkers JM (1997) Detection of spontaneous synaptic events with an optimally scaled template. Biophys J 73:220-229. CrossRef Medline

Dietz SB, Markopoulos F, Murthy VN (2011) Postnatal development of dendrodendritic inhibition in the mammalian olfactory bulb. Front Cell Neurosci 5:10. CrossRef Medline

Erzurumlu RS, Gaspar P (2012) Development and critical period plasticity of the barrel cortex. Eur J Neurosci 35:1540-1553. CrossRef Medline

Espinosa JS, Stryker MP (2012) Development and plasticity of the primary visual cortex. Neuron 75:230-249. CrossRef Medline

Feinstein P, Bozza T, Rodriguez I, Vassalli A, Mombaerts P (2004) Axon guidance of mouse olfactory sensory neurons by odorant receptors and the beta2 adrenergic receptor. Cell 117:833-846. CrossRef Medline

Fletcher ML, Wilson DA (2003) Olfactory bulb mitral-tufted cell plasticity: odorant-specific tuning reflects previous odorant exposure. J Neurosci 23:6946-6955. Medline

Fukunaga I, Berning M, Kollo M, Schmaltz A, Schaefer AT (2012) Two distinct channels of olfactory bulb output. Neuron 75:320-329. CrossRef Medline

Fukunaga I, Herb JT, Kollo M, Boyden ES, Schaefer AT (2014) Independent control of gamma and theta activity by distinct interneuron networks in the olfactory bulb. Nat Neurosci 17:1208-1216. CrossRef Medline

Galán RF, Fourcaud-Trocmé N, Ermentrout GB, Urban NN (2006) Correlation-induced synchronization of oscillations in olfactory bulb neurons. J Neurosci 26:3646-3655. CrossRef Medline

Gao Y, Strowbridge BW (2009) Long-term plasticity of excitatory inputs to granule cells in the rat olfactory bulb. Nat Neurosci 12:731-733. CrossRef Medline

Geramita MA, Burton SD, Urban NN (2016) Distinct lateral inhibitory circuits drive parallel processing of sensory information in the mammalian olfactory bulb. eLife 5: pii: e16039. CrossRef Medline

Giridhar S, Doiron B, Urban NN (2011) Timescale-dependent shaping of correlation by olfactory bulb lateral inhibition. Proc Natl Acad Sci U S A 108:5843-5848. CrossRef Medline

Gschwend O, Abraham NM, Lagier S, Begnaud F, Rodriguez I, Carleton A (2015) Neuronal pattern separation in the olfactory bulb improves odor discrimination learning. Nat Neurosci 18:1474-1482. CrossRef Medline

Haberly LB, Price JL (1977) The axonal projection patterns of the mitral and tufted cells of the olfactory bulb in the rat. Brain Res 129:152-157. CrossRef Medline

Hayar A, Karnup S, Shipley MT, Ennis M (2004) Olfactory bulb glomeruli: external tufted cells intrinsically burst at theta frequency and are entrained by patterned olfactory input. J Neurosci 24:1190-1199. CrossRef Medline

Igarashi KM, Ieki N, An M, Yamaguchi Y, Nagayama S, Kobayakawa K, Kobayakawa R, Tanifuji M, Sakano H, Chen WR, Mori K (2012) Parallel mitral and tufted cell pathways route distinct odor information to different targets in the olfactory cortex. J Neurosci 32:7970-7985. CrossRef Medline

Kapoor V, Provost AC, Agarwal P, Murthy VN (2016) Activation of raphe nuclei triggers rapid and distinct effects on parallel olfactory bulb output channels. Nat Neurosci 19:271-282. CrossRef Medline

Kato HK, Chu MW, Isaacson JS, Komiyama T (2012) Dynamic sensory representations in the olfactory bulb: modulation by wakefulness and experience. Neuron 76:962-975. CrossRef Medline

Kato HK, Gillet SN, Peters AJ, Isaacson JS, Komiyama T (2013) Parvalbumin-expressing interneurons linearly control olfactory bulb output. Neuron 80:1218-1231. CrossRef Medline

Kelsch W, Mosley CP, Lin CW, Lois C (2007) Distinct mammalian precursors are committed to generate neurons with defined dendritic projection patterns. PLoS Biol 5:e300. CrossRef Medline

Kerr MA, Belluscio L (2006) Olfactory experience accelerates glomerular refinement in the mammalian olfactory bulb. Nat Neurosci 9:484-486. CrossRef Medline

Lagier S, Carleton A, Lledo PM (2004) Interplay between local GABAergic interneurons and relay neurons generates gamma oscillations in the rat olfactory bulb. J Neurosci 24:4382-4392. CrossRef Medline

Lagier S, Panzanelli P, Russo RE, Nissant A, Bathellier B, Sassoè-Pognetto M, Fritschy JM, Lledo PM (2007) GABAergic inhibition at dendrodendritic synapses tunes gamma oscillations in the olfactory bulb. Proc Natl Acad Sci U S A 104:7259-7264. CrossRef Medline

Lemasson M, Saghatelyan A, Olivo-Marin JC, Lledo PM (2005) Neonatal and 
adult neurogenesis provide two distinct populations of newborn neurons to the mouse olfactory bulb. J Neurosci 25:6816-6825. CrossRef Medline

Lepousez G, Lledo PM (2013) Odor discrimination requires proper olfactory fast oscillations in awake mice. Neuron 80:1010-1024. CrossRef Medline

Liu S, Shipley MT (2008) Multiple conductances cooperatively regulate spontaneous bursting in mouse olfactory bulb external tufted cells. J Neurosci 28:1625-1639. CrossRef Medline

Liu S, Plachez C, Shao Z, Puche A, Shipley MT (2013) Olfactory bulb short axon cell release of GABA and dopamine produces a temporally biphasic inhibition-excitation response in external tufted cells. J Neurosci 33: 2916-2926. CrossRef Medline

Miyamichi K, Shlomai-Fuchs Y, Shu M, Weissbourd BC, Luo L, Mizrahi A (2013) Dissecting local circuits: parvalbumin interneurons underlie broad feedback control of olfactory bulb output. Neuron 80:1232-1245. CrossRef Medline

Mori K (1987) Membrane and synaptic properties of identified neurons in the olfactory bulb. Prog Neurobiol 29:275-320. CrossRef Medline

Mori K, Kishi K, Ojima H (1983) Distribution of dendrites of mitral, displaced mitral, tufted, and granule cells in the rabbit olfactory bulb. J Comp Neurol 219:339-355. CrossRef Medline

Nagayama S, Takahashi YK, Yoshihara Y, Mori K (2004) Mitral and tufted cells differ in the decoding manner of odor maps in the rat olfactory bulb. J Neurophysiol 91:2532-2540. CrossRef Medline

Nissant A, Bardy C, Katagiri H, Murray K, Lledo PM (2009) Adult neurogenesis promotes synaptic plasticity in the olfactory bulb. Nat Neurosci 12:728-730. CrossRef Medline

Orona E, Scott JW, Rainer EC (1983) Different granule cell populations innervate superficial and deep regions of the external plexiform layer in rat olfactory bulb. J Comp Neurol 217:227-237. CrossRef Medline
Orona E, Rainer EC, Scott JW (1984) Dendritic and axonal organization of mitral and tufted cells in the rat olfactory bulb. J Comp Neurol 226:346356. CrossRef Medline

Otazu GH, Chae H, Davis MB, Albeanu DF (2015) Cortical feedback decorrelates olfactory bulb output in awake mice. Neuron 86:1461-1477. CrossRef Medline

Saghatelyan A, Roux P, Migliore M, Rochefort C, Desmaisons D, Charneau P, Shepherd GM, Lledo PM (2005) Activity-dependent adjustments of the inhibitory network in the olfactory bulb following early postnatal deprivation. Neuron 46:103-116. CrossRef Medline

Smear M, Resulaj A, Zhang J, Bozza T, Rinberg D (2013) Multiple perceptible signals from a single olfactory glomerulus. Nat Neurosci 16:16871691. CrossRef Medline

Whitesell JD, Sorensen KA, Jarvie BC, Hentges ST, Schoppa NE (2013) Interglomerular lateral inhibition targeted on external tufted cells in the olfactory bulb. J Neurosci 33:1552-1563. CrossRef Medline

Wilson DA (2000) Comparison of odor receptive field plasticity in the rat olfactory bulb and anterior piriform cortex. J Neurophysiol 84:30363042. Medline

Wilson DA, Linster C (2008) Neurobiology of a simple memory. J Neurophysiol 100:2-7. CrossRef Medline

Yoshihara S, Takahashi H, Nishimura N, Naritsuka H, Shirao T, Hirai H, Yoshihara Y, Mori K, Stern PL, Tsuboi A (2012) 5T4 glycoprotein regulates the sensory input-dependent development of a specific subtype of newborn interneurons in the mouse olfactory bulb. J Neurosci 32:22172226. CrossRef Medline

Zhang J, Huang G, Dewan A, Feinstein P, Bozza T (2012) Uncoupling stimulus specificity and glomerular position in the mouse olfactory system. Mol Cell Neurosci 51:79-88. CrossRef Medline 